PART 1

Politics \& Military 
Toni Ñaco del Hoyo and Isaías Arrayás-Morales - 9789004326750 Downloaded from Brill.come4/26/2023 11:45:38AM via free access 


\title{
Rome, Pontus, Thrace and the Military Disintegration of the World Beyond the Hellenistic East
}

\author{
Toni Naco del Hoyo ${ }^{1}$ and Isaías Arrayás-Morales
}

The aftermath of the Gracchan crisis was a period of intense turmoil in many regions of Roman domain, East and West, although the loss of historical narratives such as those of Polybius and Livy have managed to shadow the scope of the troubles faced by the Republic during this period. Whereas the Cimbrian and Teutonic invasions and some regional conflicts in Sicily, Sardinia, Spain and Gaul kept the Roman armies busy in the West, in the East Macedonia, the Balkans and Asia, things were also extremely unsettled. It is possible to observe how the aftermath of certain dynastic conflicts and the ambitious political programmes endeavoured by some rulers in pursue of hegemonic dreams, as well as the continuous raids of nomadic peoples from beyond the Roman borders, directly agitated the entire region for decades. Specifically, Mithridates VI Eupator king of Pontus and several Thracian kings envisioned Rome's more active presence in Macedonia and Asia during the final decades of the second century $\mathrm{BC}$ as a threat to their military supremacy. Thus far, they had displayed garrisons and colonies, organized looting expeditions and systematically recruited foreign mercenaries for their reinforced armies. At this point, however, the Late Roman Republic's more active military policies concerning the region began to jeopardize their hegemony.

We should recall that two long-term interconnected phenomena in the Eastern Mediterranean had already caused distressing effects on neighbouring populations whose aggressive powers eventually attempted to dispute Rome's increasingly hegemonic role within the region. Firstly, the Hellenistic kingdoms had been suffering from a progressive political disintegration since the early second century. Secondly, the Roman armies had considerably increased their activities in continental Greece ever since the mid-second century, also being in charge of securing the Macedonian borders. Therefore, of relevance

1 Toni Ñaco del Hoyo is an Icrea Research Professor at Universitat de Girona. Isaíais ArrayásMorales is an Associate Professor at Universitat Autònoma de Barcelona. This research has been made possible by the following research grants: 2014SGR 1347, HAR2014-59503-P, and har2013-41629-P/Hist. All dates are BC unless otherwise indicated. 
here is the actual dimension of Roman imperialism in the face of certain new and at first sight short term challenges which however turned out to be only a snapshot of a much longer and more complex phenomenon. Furthermore, Rome was increasingly more aware of its global dominion over the oikumene which gradually evolved from hegemony in interstate relations early in the second century to what we might call a 'territorial empire' a century later, during Cicero's time: imperium orbis terrarium, eui imperio omnes gentes reges nations... consenserunt (Cic. ad Her. 4.13). ${ }^{2}$

For decades, studies of Roman imperialism have intensively examined how Rome's hegemony in the East emerged and succeeded over the last two centuries of the Republic, but our aim here is not to reappraise this lengthy debate in its entirety. ${ }^{3}$ Rather, we intend to assess the political and military strategies conducted by the Republican authorities, but only during a few decades during that same period. We wish to argue here that such strategies would eventually help Rome to integrate both Pontus and Thracia into the Imperium Romanum, especially once peace was finally reached. On the one hand, Mithridates VI Eupator, king of Pontus (120-63), a long time a close ally of Rome, had the ambition to play a central role in the agitated scenario of the interstate relations within the Black Sea region, deploying garrisons in numerous towns, promoting an interventionist dynastic policy in some of the neighbouring kingdoms, and directly defying Rome during war. Despite the treaties already signed with cities such as Mesembria, Callatis and Chersonesos, Rome's interests were bound to clash with Mithridates' expansion towards the Thracian coast, and his quest for new resources. His next claims over Paphlagonia, Galatia and Cappadocia were eventually responded to in tough diplomatic and military terms. But, despite his long lasting friendship with Mithridates, is it possible that Rome never foresaw his actual ambitions towards the western and northern Black Sea coasts?

2 See also Cic. Off. 2.27. P.A. Brunt, 'Laus Imperii', Roman Imperial Themes (Oxford 1990), pp. 291293, 297-300; G. Kellon, 'The rise of Global Power and the Music of the Spheres: Philosophy and History in Cicero's De re publica', in D.E. Tabachnick, T. Koivukoski (eds.), Enduring Empire. Ancient Lessons for Global Politics (Toronto 2009), pp. 147-163; D.J. Mattingly, 'From imperium to imperialism', Imperialism, Power and Identity. Experiencing the Roman Empire (Princeton 2011), pp. 3-42; L. Beness, T. Hillard, 'Rei militaris virtus ... orbem terrarium parere huic imperio coegit: The Transformation of Roman Imperium, 146-5o BC', in: D. Hoyos (ed.), A Companion to Roman Imperialism (Leiden-Boston 2013), pp. 141-153.

3 See, most recently A.M. Eckstein, Mediterranean Anarchy, Interstate War, and the Rise of Rome (Berkeley 2006), pp. 79-117; D.W. Baronowski, Polybius and Roman Imperialism (London, 2011), pp. 71-72; O. Hekster, 'Kings and Regime Change in the Roman Republic', in Ch. Smith \& L.M. Yarrow (eds.), Imperialism, Cultural Politics \& Polybius (Oxford, 2012), pp. 184-202. 
On the other hand, the decay and eventual extinction of most of the Hellenistic monarchies as employers for mercenaries and auxiliaries from the Thracians and other nomadic tribes led to a major disturbance within and beyond their frontiers. It is not surprising to see how the Thracians, Sarmatians and Scordisci eventually moved from the steppes of Southern Ukraine to raid Macedonia, Illyria and other regions under Roman control. Yet, though some Thracian auxiliaries were recruited during the Mithridatic Wars, Rome never became a proper mercenary employer as the old Hellenistic powers used to be. So, the open confrontation against the Thracians in several wars from the late second century was Rome's last resort to resolve the unrest caused by their continuous raids into Roman territory when it was not feasible to enrol these individuals as mercenaries?

\section{$\mathbf{1}$ \\ Towards the Integration of the Pontic Territories in the Roman World}

Rome showed interest in the eastern Mediterranean ever since the earliest phases of Republican expansion towards the Hellenistic world. But it was not until the leadership of Gaius Marius and his supporters that Rome itself engaged in the area of the Black Sea, as a result of the aggressive expansion undertaken there by king Mithridates of Pontus. Rome could have ordered the withdrawal of the Pontic monarch from the territories conquered to the Scythian kings, as occurred in regards to the Anatolian regions of Paphlagonia and Cappadocia (Memn. 22.3-4). However, evidence suggests that Mithridates' early victories in the Bosporus and Colchis, and his triumphs over Scythians, Sarmatians, Bastarnae, and other northern Black Sea populations were not a cause for alarm in Rome. Thus, the king was free to proceed with his policy. This lax attitude on behalf of Rome may be explained by the fact that these were distant lands, in which the Senate clearly had no interests. Also, his status as a "friend and ally" of Rome meant that his raids indirectly served to extend Roman hegemony to those regions. Furthermore, between 113 and 101, Rome was engaged in wars against the Numidian king Jugurtha, and against the Cimbrians, who were now threatening the territory of Italy. No doubt, this difficult political and military situation in the West surely played a role in Rome's laissez-faire approach to Pontic expansion in the Black Sea, and also promoted Mithridates' intervention in Anatolia. ${ }^{4}$

4 A.N. Sherwin-White, Roman Foreign Policy in the East 168 BC to AD 1 (London, 1984), pp. 106-107, 134; B.C. McGing, The Foreign Policy of Mithridate VI Eupator (Leiden, 1986), pp. 37-38, 
The king's raids of Anatolia finally compelled Rome to react, and marked the beginning of the escalation leading to the Mithridatic wars. Clearly, Rome could not tolerate a powerful and hostile Pontic kingdom on the border of such an important province as Asia. It had already taken steps to constrain this possibility, such as the addition to the province of all the lands of the Attalid kingdom rendered in 129/126 to the kings of Pontus, Cappadocia and perhaps Bithynia, all of whom were allies in the war against Aristonicus (Str. 10.4.10; App. Mith. 11-13, 15, 56; Iust. 37.1.6, 38.5.6). ${ }^{5}$ Also, Rome was forced to contend with Mithridates' increasing prestige in the Greek world, at a time when antiRoman sentiment was on the rise, generated in large part by the rapacity of the Italian businessmen. ${ }^{6}$ Thus, it is not surprising that the Athenians honored him with an inscription in Delos, and even with a small temple in 102/101. ${ }^{7}$ Likewise, Chiotians and Rhodians erected statues and produced inscriptions in his honor (Cic. Verr. 2.2.159). ${ }^{8}$ Such unrest in Anatolia dovetailed with the goals of the Marians, who, after the victory over Jugurtha and the Cimbrians, sought to restore Rome's honor through war, an ideal that was perfectly represented in the templum Honoris et Virtutis Marianum (Cic. Pro Sest. 116, Pro Planc. 78; Vitr. 3.2.5). ${ }^{9}$ All of this explains the rudeness with which Lucius Appuleius Saturninus treated the Pontic ambassadors dispatched to Rome in 102/101 (Diod. 36.15.1). It was followed in 99/98 by a diplomatic expedition of Marius to Galatia and Cappadocia, perhaps already anticipating a leading role in a potential war with Pontus (Plut. Mar. 31 ; Diod. 37.29.2). ${ }^{10}$ In any event, once Rome resumed its international leadership in the West in 101, it continued to

63-64, 66-88, 108, 173-175; R.D. Sullivan, Near Eastern Royalty and Rome, 10o-3o BC (Toronto, 1990), pp. 51-58; L. Ballesteros, Mitrídates Eupátor, rey del Ponto (Granada, 1996), pp. 43-71. RDGE 13; OGIS 436; IGRR 4, 752; Cnidos, col. III, ll. 22-27. T. Drew-Bear, 'Three Senatus Consulta concerning the Province of Asia', Historia 21 (1972), pp. 81-82; McGing, The Foreign Policy, pp. 41-42, 67-68; R.K. Sherk, Roman and the Greek East to the Death of Augustus (Cambridge 1984), pp. 53-54 (n. 49); M. Crawford, Roman Statutes (London, 1996), pp. 231-271 (n. 12).

6 McGing, The Foreign Policy, pp. 64, 89-108, 122.

7 OGIS 368-369; I. Délos 1560-1561, 1564-1568, 2039-2040; with a small temple in 102/101 see I. Délos 1552, 1569-1574, 1576, 1581-1582.

8 McGing, The Foreign Policy, pp. 89-93; P.-A. Kreuz, 'Monuments for the King: Royal Presence in the Late Hellenistic World of Mithridates VI', in Mithridates VI and the Pontic Kingdom (Aarhus, 2009), pp. 131-144.

9 A. Mastrocinque, Studi sulle guerre Mitridatiche (Stuttgart, 1999), p. 25; E. Bertrand, 'Sur les couronnes de Sylla (et sur la couronne civique à la fin de la République romaine et au début du Principat)', in Hommages à François Hinard (Paris, 2010), pp. 23-38.

10 T.J. Luce, 'Marius and the Mithridatic Command', Historia 19 (1970), pp. 166-168; M. Sordi, 'La legatio in Cappadocia di C. Mario nel 99-98 a.C.', RIL 107 (1973), pp. 370-379; McGing, The Foreign Policy, pp. 59, 71-72, 76; Mastrocinque, Studi sulle guerre, pp. $25^{-27}$. 
avoid taking any harsh measures against Pontic expansion in the Black Sea. In addition, it should be noted that Mithridates, as a "friend and ally", attempted to maintain diplomatic ties with the Roman state, leaving, at least in part, his plans of expansion in Anatolia. Furthermore, during this period, Rome expressed a surprising lack of interest in Pontic affairs.

Indeed, it cannot be said that Mithridates implemented a hostile policy towards Rome. With his expansion in the Black Sea, as well as in Anatolia, the king went after the creation of a stronger Pontic State, exercising hegemonic power in the coastal lands along the Black Sea and neutralizing rival kingdoms. He carried out the same policies as all of his predecessors since Pharnaces I had done, all of whom had also been "friends and allies" of Rome. But his expansionist success led him to a sure collision with Roman interests in Anatolia. This may easily explain why his ties with Rome were maintained until the very last moment before the war. Actually, it is generally considered that he never in fact expected the attack on Pontus by Nicomedes IV of Bithynia in 89 (Memn. 22.7) at the instigation of the propraetor Gaius Cassius and the legate Manius Aquillius (App. Mith. 11; D.C. 99), both influential members of the Marians. Likewise, Cassius and Aquillius, without sufficient troops to start a war, were not expecting such a brutal response from a sovereign who had always complied with Rome's decisions (App. Mith. 19).11

Mithridates began his expansion along the coast of the Black Sea around 111/110, apparently with no significant political reaction in Rome, according to the scarce evidence existing on the matter. Therefore, although thus far the king had never betrayed the Republic's favour as a "friend and ally," he was determined to extend his power over Chersonesos Taurica, Olbia, Tyras, Theodosia, Pantikapaeum, Phanagoria, and Gorgippia (Str. 7.4.3-7). ${ }^{12}$ In doing so we should not deny that Mithridates, much like his predecessors, took advantage of the fragility of these poleis to the barbarians and also of Rome's inability to offer them effective assistance. Two decrees from Olbia refer to these affairs. The first, in honor of Neikeratos, noted the constant pressure put on the polis by the barbarians at the beginning of first century. ${ }^{13}$ The second, honoring a Pontic general from Amisos, indicated the presence of a Mithridatic garrison. ${ }^{14}$ As a reward for the campaigns that he led between 111 and 107, Mithridates

\footnotetext{
11 McGing, The Foreign Policy, pp. 80-83, 108-131; T.C. Brennan, The Praetorship in the Roman Republic, II (Oxford, 2000), pp. 555-556.

Syll ${ }^{3}$ 709; IOSPE $\mathrm{I}^{2} 35^{2}$.

Syll $^{3} 730 ;$ IOSPE $\mathrm{I}^{2} 34$.

IOSPE $\mathrm{I}^{2}$ 35. McGing, The Foreign Policy, pp. 46-48, 50-57; V. Krapivina, 'Problems of the Chronology of the Late Hellenistic Strata of Olbia', in Chronologies of the Black Sea Area in the Period c. 400-100 BC (Aarhus, 2005), p. 251.
} 
was also crowned monarch of the Bosporus when its last ruler, Paerisades V, bestowed the kingdom upon him (Str. 7.3.17, 7.4.3-6; Iust. 37.3.1-2, 38.7.4-5). Along with these victories, around 105 and 100, the annexation of Colchis and Armenia Minor took place, granted by its king, Antipater (Str. 11.2.13, 11.2.18, 12.3.1, 12.3.28; App. Mith. 15, 17; Memn. 22.4; Iust. 38.7.10; Eutr. 5.1; Oros. 6.2.1). ${ }^{15}$

Eventually, territories along the northern and eastern coasts of the Black Sea were annexed and garrisoned by Pontus, and Mithridates appointed his sons and philoi as éparchoi in charge of them (Str. 7.4.3-7). Along the western coastline, on the other hand, Pontic hegemony was extended through alliances with the poleis (symmachiai). ${ }^{16}$ Thus, the proximity of the province of Macedonia must have served to limit his interventions. However, the serious problems affecting the province at the end of the second century, with its borders under constant threat by the barbarians, facilitated the king's activity in the region. Therefore, we have two inscriptions from the nineties, one from Istros and the other from Apollonia, honoring two Pontic strategists. ${ }^{17}$ In addition, several texts show that Marcus Terentius Varro Lucullus, proconsul of Macedonia in 72/71, forced most towns from the Thracian coast to capitulate (Liv. Per. 97; App. Illyr. 30; Sall. Hist. 4.18; Amm. 27.4.11; Eutr. 6.10; Fest. 9.3; Oros. 6.3.4) and accept the quartering of Roman garrisons, serving as proof of their bond with Pontus. ${ }^{18}$

In an unprecedented way, Mithridates attempted to unite the Black Sea under his control, in order to strengthen the link between these regions and the Pontus, and to promote the recovery of their economies after the end of the conflict with the barbarians. Thus, according to the evidence, the king was Chersonesos Taurica's protector (prostates) (Str. 7.4.3), intensifying the bond established by a previous treaty signed by Pharnaces I. ${ }^{19}$ Also, two decrees from Chersonesos report these circumstances: a decree in honor of a Pontic ambassador who had possibly brought the king's reply to the city's request for help;

15 McGing, The Foreign Policy, pp. 58-61; Ballesteros, Mitrídates Eupátor, pp. 53-54.

16 J.M. Hojte, 'The Administrative Organisation of the Pontic Kingdom', in Mithridates VI and the Pontic Kingdom (Aarhus, 2009), pp. 95-107.

17 AE 1997, 1316 = SEG 47, 1125; IGBulg. I $^{2} 392$.

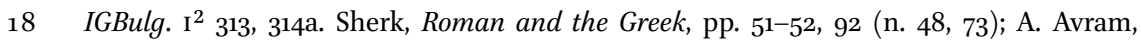
O. Bounegru, 'Mithridate VI Eupator et la côte ouest du Pont-Euxin. Autour d'un Décret inédit d'Istros', Pontica 30 (1997), pp. 155-165; Brennan, The Praetorship in the Roman, pp. 521-522, 528-533, 560-564, 584; P. Delev, 'The burning of the temple at Delphi, the Roman governor L. Scipio and the rout of the scordisci', in Armées grecques et romaines dans le nord des Balkans (Gdansk, 2013), pp. 91-103.

19 IOSPE $\mathrm{I}^{2}$ 402. J.M. Hojte, "The Date of the Alliance between Chersonesos and Pharnakes (IOSPE $\left.\mathrm{I}^{2} 402\right)$ and its Implications', in Chronologies of the Black Sea Area in the Period c. 400-100 BC (Aarhus 2005), pp. 137-152. 
and a decree honoring the general Diophantos, who took part in three campaigns in Taurica (Str. 7.4.3-7). ${ }^{20}$ Specifically, the latter document reflects the troubles of Chersonesos, and of the other towns in the area, since the barbaric pressure at the end of second century. It also shows the gratitude of the city's population towards the Pontic troops that had helped defend them, despite eventually losing its freedom. ${ }^{21}$

It should also be noted that, since the last decade of the second century, the king's coinage spread over the regions under his control. These coins came primarily from Amisos and, to a lesser extent, from Sinope, indicating that there was an attempt to strengthen economic and politic relations in the Black Sea region. It should be stressed that the coastal regions, especially the northern ones, were allowed to overcome the deep crises that they were suffering from, due to the barbarian threat, with trade even being encouraged with the inland tribes, in which the poleis acted as third party. Therefore, these lands became an essential source of supplies, permitting the king's long war against Rome (Str. 7.4.6, 11.2.18; App. Mith. 69; Memn. 32-38). However, once again, they fell into decline following the war destruction in 63 , as well as a result of factors such as poor management by the Pontic satraps, the blockade raised by Pompeius Magnus, and the tax demands imposed upon them by Mithridates. Thus, for him, once expelled from Anatolia, the Bosporus became his principal possession. $^{22}$

\section{Rome and the Thracians at the Beginning of the Late Roman Republic}

Located in the Eastern Balkans, between the Danube in the North (Istros, in Greek) and the Aegean in the South, the Thracians were an amalgamation of

$20 \quad$ IOSPE I I ${ }^{2} 349$; Syll ${ }^{3} 709 ;$ IOSPE $\mathrm{I}^{2} 35^{2}$.

21 P. Foucart, 'Décret de la ville de Chersonesos en l'honneur de Diophantos, Général de Mithridate', $B C H 5$ (1881), pp. 70-87; L. Boffo, 'Grecità di frontiera: Chersonasos Taurica e i signori del Ponto Eusino (sIG 3 709)', Athenaeum 67 (1989), pp. 211-259, 369-405; J.A. Vinogradov, 'Two Waves of Sarmatian Migrations in the Black Sea Steppes during the Pre-Roman Period', in The Cauldron of Ariantas (Aarhus, 2003), pp. 217-226.

M.J. Price, 'Mithridates Eupator Dionysos and the Coinages of the Black Sea', NC 8 (1968), pp. 1-12; F. de Callataÿ, 'Coins and Archaeology. The (mis)use of Mithridatic Coins for Chronological Purposes in the Bosporan Area', in Chronologies of the Black Sea Area in the Period c. 400-100 BC (Aarhus, 2005), pp. 119-136; S.J. Saprykin, 'The Unification of Pontos: the Bronze Coins of Mithridates VI Eupator as Evidence for Commerce in the Euxine', in The Black Sea in Antiquity (Aarhus, 2007), pp. 195-207. 
tribes contemporary to the Greek and Roman world. There is little agreement as to whether or not the Thracians shared an Indo-European language, ethnicity, culture and a lifestyle based on their strong dominion of warfare and horses. There is still much to be understood about their political organization, except for the Ordrysian tribe whose royal institutions have been well attested to since the sixth century, thanks to the interest of some classical authors. ${ }^{23}$ Although most of our historical record has been provided by the archaeology, coins and art of such people, literary evidence from the Graeco-Roman tradition provides an alien perspective that usually depicts the Thracians as skilled and fierce warriors and cavalrymen with a particularly brutal attitude towards its enemies at war. Never playing a minor role in foreign politics, for centuries the Thracians were often hired by neighboring powers and distant empires to serve as mercenaries and auxiliaries who efficiently devoted themselves to war and plunder on behalf of their employers. ${ }^{24}$

In this section of the paper we shall focus on the study of the role played by the Thracians as warriors on behalf of external powers in the Late Hellenistic period, when Rome decisively crossed the boundaries of 'multipolarity' in pursuit of a more hegemonic power in the East. In fact, the Republic's more direct intervention in Eastern affairs since early the second century slowly distorted

23 A. Fol, I. Marazov, Thrace \& The Thracians, (New York, 1977), pp. 144-154; Z.H. Archibald, The Ordrysian Kingdom of Thrace. Orpheus Unmasked (Oxford, 1998), esp. pp. 5-25, 93-125; 213-259; A. Hyland, 'War and the horses. Part I Horses for War. Breeding and keeping a Warhorse', in: B. Campbell, L. Tritle (eds.), The Oxford Handbook of Warfare in the Classical World (Oxford 2013), pp. 493-511 (pp. 493-494); D. Graninger, 'Etnicity and Ethne', in J. Valeva, E. Nankov, D. Graninger (eds.), A Companion to Ancient Thrace (Oxford 2015), pp. 22-32; Z. Archibald, 'Social Life of Thrace', Companion to Ancient Thrace, pp. 385-398 (pp. 393-395).

24 Ath. 4.155e; Hdt. 5.3; 6; Thu. 2.96-97; 7.29.4; Amm. 27.4.4; Flor. 1.39.3. M. Launey, Recherches sur les armées hellénistiques (Paris 1987), reipr. 1949, vol. 1, pp. 366-398 (pp. 386-389); Ch. Webber, The Thracians 700 BC-AD 46, Osprey Men-at Arms 360 (Hailsham 2001); S. Kirov, 'L'image des Thraces à Rome du IIè.s. avant au IIIè.s. après N.E.', in Proceedings of the 1oth International Congress of Thracology (Komotini-Alexandrooupolis 18-23 October 2005) (Athens, 2007), pp. 304-307; D. Dana, 'Les Thraces dans les armées hellénistiques: essai d'histoire par les noms', in J.-Ch. Couvenhes, S. Crouzet, S. Péré-Noguès (eds.), Pratique et identities culturelles des armées hellénistiques du monde méditerranéen, Scripta Antiqua 38 (Bordeaux, 2011), pp. 87-115 (pp. 88-90); A. Sobotkova, 'Resisting rule in ancient Thrace', in M. Manoledakis (ed.), Exploring the Hospitable Sea. Proceedings of the International Workshop on the Black Sea in Antiquity held in Thessaloniki, 21-23 September 2012, BAR Int.Ser. 2498 (Oxford, 2013), pp. 133-146 (pp. 134-136). 
the traditional picture of the Thracians as fortune warriors and looters. ${ }^{25}$ According to Livy, the Roman legions in Magnesia were reinforced by 2,00o Thracian and Macedonian 'voluntary soldiers' (qui voluntate secuti erant), whatever the exact meaning of such 'voluntary' service may have been, possibly referring to soldiers enrolled following the clauses of any alliance treaty not explicitly mentioned in the same passage (Liv. 37.39.12). ${ }^{26}$ Therefore, unlike what was a common practice for most of the Hellenistic monarchies thus far, mercenary trade was hardly at the core of Roman and Thracian relations during the first decades of Republican expansionism to the East. Our data seems to suggest that this issue remained constant over the following decades and would not change until Thrace became a Roman province during the Roman Principate.

Although L. Scipio (cos. 190) headed for Thrace with Macedonian support in 190 (Liv. 37.7.16), Rome's first military encounters with the Thracians are dated back to 188. Then, Cn. Manlius Vulso (cos. 189) who had been in charge of the Roman-Aitolian peace, led an expedition to Hellespont, Chersonese and Thrace, being ambushed several times by the Thracians but ultimately defeating them (Liv. 38.40-41). ${ }^{27}$ Later, Perseus of Macedon employed Thracian soldiers in his armies during the final war against Rome, while at the same time, the latter strengthened its diplomatic ties with several Thracian tribes, seeking external support for his cause (Liv. 42.19.6). ${ }^{28}$ But, after the defeat at Pydna in 168, the entire Macedonian court was captured and deported to Rome and a Thracian prince called Bithys, son of king Cotys viII, was among the distinguished individuals imprisoned in Rome. Nevertheless, instead of following Perseus' dramatic destiny, the Republican authorities merely held Bithys as a hostage for some time, being advisedly educated before sending him back to his father in Thrace (Liv. 45.42.5-12). ${ }^{29}$

25 See most recently, P. Delev, 'From Koroupedion to the Beginning of the Third Mithridatic War (281-73 BCE)', in J. Valeva, E. Nankov, D. Graninger (eds.), A Companion to Ancient Thrace (Oxford, 2015), pp. 59-74 (pp. 68-72).

26 J. Krasilnikoff, 'Mercenary soldiering in the West and the development of the army of Rome', Analecta Romana Instituti Danici, 23 (1996), pp. 7-20 (p. 15).

27 J. Briscoe, A Commentary on Livy Books 38-4o (Oxford, 2008), p. 148; M. Zahariade, The Thracians in the Roman Imperial Army. From the first to the third century AD, vol. I, Auxilia (Cluj-Napoca, 2009), pp. 39-40.

28 M. Zahariade, The Thracians, p. 42.

29 Syll ${ }^{3}$ 656; D.C. Braund, Rome and the Friendly King (London, 1984), p. 16; C. Eilers, 'Introduction', in C. Eilers (ed.), Diplomats and Diplomacy in the Roman World (LeidenBoston, 2009), p. 9. 
It should be stressed that in the aftermath of Perseus' defeat, Rome imposed its unilateral conditions on a Thracian king who had formerly been under Macedonian influence. From this moment on, the slow but progressive decay of Thracian mercenary recruitment by foreign powers became a decisive side effect of Rome's growing dominion over the East. For instance, Andriscus, the pretender to the Macedon throne who led an uprising against Rome in 150, actually received active military support from some Thracian tribes. Two years later, after being defeated in Macedonia, Andriscus fled to Thrace, seeking refuge and being finally betrayed by Byzes, a Thracian prince (Zon. 9.28). ${ }^{30}$ Although some Greek towns continued to enroll Thracian soldiers, when the military hegemony of the Hellenistic monarchies diminished and eventually vanished, particularly during the second half of the second century BC, the actual number of potential employers also followed the same pattern. Accordingly, there was major stress in the daily lives of many Thracians who had previously serve as mercenaries in regular foreign armies outside of Thrace. ${ }^{31}$

In 141 some raids from the Scordisci, Celtic Gauls known even in Strabo's time for their occupation as brigands (Str. 7.5.12), ${ }^{32}$ were briefly reported on in Livy's summaries (Liv. Per. 54), along with new actions undertaken to defend such territories in 135 when again only a few lines in Livy outline a Roman expedition led by M. Cosconius, a praetor serving in the Roman province of Macedonia that year and who defeated the same nomadic people (Liv. Per. 56). ${ }^{33}$ According to the historical record, these raids ceased for some

30 L.D. Loukopoulou, 'Provinciae Macedoniae Finis Orientalis. The Establishment of the Eastern Frontier', in M.B. Hatzopoulos \& L.D. Loukopoulou, Two Studies in Ancient Macedonian Topography (Athens, 1987), pp. 61-110, esp. p. 68; R. Kallet-Marx, Hegemony to Empire. The Development of the Roman Imperium in the East from 148 to 62 BC (BerkeleyLos Angeles-Oxford, 1995), pp. 34-37.

31 K. Sion-Jenkins, 'La disparition du mercenariat en Asie Mineure occidentale au IIè. Siècle a.C.: éléments de réflexion', in A. Bresson, R. Descat (eds.), Les cités d'Asie Mineure occidentale au IIè. Siècle a.C. (Bordeaux, 2001), pp. 19-35; contra. J.-Ch. Couvenhes, 'Les cités grecques d'Asie Mineure et le mercenariat à l'époque hellénistique', in J.-Ch. Couvenhes \& H.-L. Fernoux (dir.), Les cités grecques et la guerre en Asie Mineure à l'époque hellénistique (Tours, 2004), pp. 77-113 (pp. 105-106).

32 R. Kallet-Marx, Hegemony to Empire, p. 38. See recently, J. Emilov, 'Celts', in J. Valeva, E. Nankov, D. Graninger (eds.), A Companion to Ancient Thrace (Oxford 2015), pp. 365-381 (pp. 374-375).

33 T.C. Brennan, The Praetorship, vol. 1, pp. 227-229 and pp. 345-346; M.-G. Parissaki, 'Thrace under Roman sway (146 BC-AD 46) between warfare and diplomacy', in A. Rufin Solas (ed.), Armées grecques et romaines, pp. 105-114 (pp. 106-108). 
time but they surely meant a serious affront not only on the provincial territories of Macedonia themselves, but also for Rome's growing interest in the East. ${ }^{34}$

During roughly the same period, most likely over the third quarter of that century, a new road-building program (known to us as via Egnatia) was launched in Illyria and Macedonia. ${ }^{35}$ As had previously occurred in Italy or in other Mediterranean regions during the last quarter or that same century, roads were necessary in order to accomplish military objectives by securing the quick mobility of the legions and their supplies. Only when such roads were fully operative and the unrest eventually diminished due to the presence of the armies, could private businessmen also travel across them, in search of new markets. Traders and entrepreneurs of Italian or Roman origins had already settled in Macedonia and Illyria over the second half of the century, and they surely made use of such transport resources when necessary. ${ }^{36}$ In fact, M.H. Crawford points out that the huge quantity of Roman denarii and Greek local issues hoarded in Dacia and Thrace since the mid-first century attests to the massive transactions related to slave trade, which were privately organized after the Thracian and pirate campaigns late in the second century. More recently, however, alternative but reasonable explanations have been suggested by A. Meta. Specifically, she relates the increased circulation in Dacia and Thrace of Roman issues as well as drachmae from Dyrrachion to payments for mercenary and auxiliary troops. ${ }^{37}$

34 L. Amela Valverde, 'Sexto Pompeyo, gobernador de Macedonia, y las incursions escordiscas ca. 120-100 a.C., Iberia 7 (2004), pp. 19-38 (p. 26).

35 F.W. Walbank, A Historical Commentary on Polybius, vol. 3 (Oxford, 1979), pp. 622-638; R. Kallet-Marx, 'Appendices. C. The date of the Via Egnatia', in Hegemony to Empire, pp. 347-349; Y. Lolos, 'Via Egnatia after Egnatius: imperial policy and inter-regional contacts', Mediterranean History Review 22.2 (2007), pp. 273-293 (pp. 274-275); A. Karivieri, 'Creating contacts. Trade and exchange along the Via Egnatia from the Roman to the early Byzantine period', Bollettino di archeologia on line [<http://151.12.58.75/archeologia $\rangle]$ 1 (2011) edizione speciale, C. 11.3., pp. 15-22.

$3^{6}$ A. Rizakis, 'Lémigration romaine en Macédoine et la communauté marchande de Thessalonique. Perspectives économiques et sociales', in Ch. Müller, Cl. Hasenohr (eds.), Les Italiens dans le monde grec. II e siècle av. J.-C.--Ir ap. J.-C., Suppl. всн (Athens, 2002), pp. 109-132 (pp. 110-112); S. Shpuza, 'Illyriens et romains. Du conflit à l'intégration', in A. Rufin Solas (ed.), Armées grecques et romaines, pp. 133-143 (pp. 140-141).

37 M.H. Crawford, 'Republican denarii in Romania: the suppression of piracy and the slave-trade', Journal of Roman Studies 67 (1977), 117-124; A. Meta, 'Guerre et circulation monétaire: le cas des drachmes de Dyrracchion', A. Rufin Solas (ed.), Armées grecques et romaines, pp. 117-131, (pp. 122 ff.). 
Triumphs over populations from the Balkans such as Delmatians in 155 and Iapydes in 129 are briefly mentioned in the Fasti Triumphales. ${ }^{38}$ The kingdom of Pontus became the main royal employer of mercenaries in the East, particularly following the extinction of the Attalid dynasty in 133 . Mithridates $\mathrm{V}$ Evergetes (c. 150-120) and a faithful ally of Rome's in Anatolia, sent one of his officers-Dorylaos-to recruit mercenaries in Thrace, Greece and especially in Crete, where the abundant mercenary soldiers of the island were also hired by pirate groups (Str. 10.4.10). ${ }^{39}$ After 133, the Thracians sided with Aristonikos (=Eumenes III) and joined his armies against Rome, serving as mercenaries, contributing to the consul P. Licinius Crassus Mucianus' defeat in 130 (Val. Max 3.2.12; Oros. 5.10.3)..$^{40}$ The Thracian incursions continued to cause great anxiety in Greek towns, as may be observed in a contemporary inscription from Sestos, a town located in the Thracian shore of the Hellespont. ${ }^{41}$ Similarly, according to another long-debated inscription from Lete, near Thessaloniki, dated 120/119, the Scordisci defeated a Roman commander called Sextus Pompeius, possibly a praetor. ${ }^{42}$ Unfortunately, the latter is only known thanks to this text. The full command of the remaining forces was left to Marcus Annius, Pompeius' quaestor, whose name is honored by this inscription. Annius managed to expel the invaders with the support of the Thracians Medii. ${ }^{43}$ The unrest in the Balkans was perhaps triggered by the initial expeditions of the Cimbrians and other Germanic tribes from Jutland to Thrace and Illyria, as well as by the alliance between Scordisci and some Thracians against the Romans. An extraordinary piece of what has been sometimes described as Thracian art from the last decades of the second century, the Gundestrup Cauldron, may offer indirect evidence for such migrations since it was located in Himmerland, Northern Jutland. However, this last historical interpretation

38 A. Degrassi, Fasti Capitolini. Recensuit, praefectus est, indicibus instruxit (Torino, 1955), pp. 105-106; D. Dzino, Illyricum in Roman Politics, 229 BC-AD 68 (Cambridge, 2010), p. 63, p. 72 .

39 F. Durrbach, Choix d'Inscriptions de Délos, t.I. (Paris, 1921), p. 156, pp. 217-218.

40 A.-J. Reinach, 'Les mercenaires et les colonies militaires de Pergame', Revue d'Archeologie 14.2 (1909) 55-70, esp. pp. 68-69; Ma.L. Sánchez León, 'Les Thraces dans les armées d'Eumène III de Pergame', in P. Roman (ed.), The Thracians at the crossroads of civilization: proceedings of the seventh international congress of thracology (Bucharest, 1997), pp. $392-398$.

41 OGIS 339, lin. 18; BE 1981, n. 328 (pp. 419-420); P. Delev, 'From Koroupedion', p. 69.

$42 \quad S I G^{3} 700 ; M R R$ I, 526.

43 F. Papazoglou, The Central Balkan tribes in pre-Roman times. Triballi, Autariatae, Dardanians, Scordisci and Moesians (Amsterdam, 1978) pp. 116-118; 288 ff.; L. Amela Valverde, 'Sexto Pompeyo, p. 27. 
is still controversial amongst the scholars who have studied the Cauldron, especially since it is only based on one single object, notwithstanding the fact that it contains precious and rare cultural images belonging to a world far from Jutland. ${ }^{44}$

Around 114/113, Rome faced some major new foreign policy challenges. Cimbrians and other Germanic peoples who had remained in Illyricum for some years headed towards the Alpine regions, Gaul, Spain and finally Italy in what has been recently described as the most dangerous invasion suffered by Rome's dominion since Hannibal. ${ }^{45}$ In addition to such massive migrations, we know of Jugurtha's war in Numidia, the uprisings in Further Spain and Sardinia, and a new slave uprising in Sicily. ${ }^{46}$ On the eastern front, however, the situation was little better, particularly, on the one hand, between 114 and 106 and on the other, until $97 .{ }^{47}$ Most of these events took place immediately after the Thracians and Scordisci raided Macedonia, Thessaly and even Dalmatia (Flor. 1.39.1). At any rate, such a stressful time in the Eastern provinces coincided with a period when the West was also in turmoil. ${ }^{48}$ For instance, according to Frontinus the Scordisci besieged and subsequently killed eight-hundred men and their Roman garrison commander-Lucullus-from a town called Heraclea (Front. 3.10.7). The passage does not provide any clear indication as to Heraclea's exact location or time. Nevertheless, it may possibly be attributed to Heracleia Sintike, a Greek town located between Macedon and Thrace

44 F. Kaul, 'The Gundestrup Cauldron and the Periphery of the Hellenistic World', in P. Bilde et alii (eds.), Centre and Periphery in the Hellenistic World (Aarhus, 1993) pp. 39-52 (pp. 47-49); S. Nielsen et alii, 'The Gundestrup Cauldron. New scientific and technical investigations' Acta Archaeologica 76 (2005), 1-58, (pp. 53-54).

45 Liv. Per. 63: Cimbri, gens vaga populabundi in Illyricum venerunt. See E. Demougeot, 'Linvasion des Cimbres—Teutons-Ambrons et les Romains' Latomus 37 (1978), pp. 910938 (pp. 933 ff.); R.J. Evans, 'Rome's Cimbric Wars (114-101 BC) and their impact on the Iberian Peninsula' Acta Classica 48 (2005), pp. 37-56 (p. 54).

46 C.F. Konrad, 'From the Gracchi to the First Civil War', in N. Rosenstein \& R. Morstein-Marx (eds.), A Companion to the Roman Republic (Oxford 2006), pp. 167-189.

47 For a complete record of these events see: F. Papazoglou, The Central Balkan, 294-314; L. Amela, 'Sexto Pompeyo, pp. 30-32; M. Zahariade, The Thracians, pp. 43-47.

48 Taking into account Mithridates vi's insistence in gathering all sorts of information on Pontus, it may be tempting to suggest that the Thracians and Scordisci could have been somehow informed of Rome's difficulties in the West during that same time period, although the truth is that we have no direct evidence to prove this. See, T. Naco, 'Roman and Pontic intelligence strategies. Politics and war in the time of Mithridates VI', War in History 21.4 (2014), pp. 401-423. 
which surely suffered a stressful time during the Thracian Wars. ${ }^{49}$ However, the real scope of the threat posed by the Thracian campaigns may be inferred from the regular dispatching of four consuls and several proconsuls to Macedonia as their provincia and Thrace as their actual military destiny. ${ }^{50}$ Whereas C. Porcius Cato's (cos. 114) was defeated while still in office and was found guilty of extortion upon safely arriving in Rome after his campaign, ${ }^{51} \mathrm{M}$. Minucius Rufus (cos. 110) remained in the region as a proconsul until 106, celebrating his triumph over Scordisteis et Thraecibus, according to the Fasti Triumphales (106), and also over the Besii and others. ${ }^{52}$ The core of the campaigns against the Thracians and other nomadic peoples from the North Balkans ended in 106, but it was never an easy victory for Rome and was certainly not a definitive one. For instance, in 104, Julius Obsequens briefly mentions the defeat of Thracians in Macedonia (Obs. 43). Then, T. Didius (cos. 98 in Nearer Spain) who was most likely a praetor in Macedonia in 101, possibly celebrated a triumph over Thracians or Scordisci after holding office in that province (Cic. Pis. 61$) .53$ Didius is also mentioned in the Lex de Provinciis Praetoriis, most often dated

49 F. Papazoglou, Les villes de Macédoine à l'époque romaine (Paris, 1988), pp. 368-371; G. Mitrev, 'Civitas Heracleotarum. Heracleia Sintica or the Ancient City at the Village of Rupite (Bulgaria)' Zeitschrift für Papyrologie und Epigraphik 145 (2003), pp. 263-272, (pp. 267 ff.).

$50 \quad$ C. Porcius Cato (cos. 114, Macedonia): defeated by Scordisci (Liv. Per. 63; Vel. 2.7.8-2.8.1; Flor. 1.39.1-5; Dio 26. Fr. 88; Amm. 27.4.4; Eutr. 4.24; Fest. Brev. 9.1); C. Caecilius Metellus Caprarius (cos. 113, Macedonia): campaigning in Thrace(Vell. 2.8.2; Eutr. 4.25; Fast.Triumph. (111); CIL I $\left.{ }^{2} .1,200,35\right) ;$ M. Livius Drusus (cos. 112 Macedonia, procos. 111 Macedonia): campaigning in Thrace against the Scordisci (Liv. Per. 63; Flor. 1.39.5; Fest. Brev. 9.2; Amm. 27.4.10; Dio 26. Frg. 88; Syll. ${ }^{3}$ 705, C 62-64; IG 7. 2413-2414; Fast.Triumph. (110); M. Minucius Rufus (cos. 110, Macedonia; procos. 109-106 Macedonia) actively campaigning in Thrace (Sal. Iug. 35.4; Liv. Per. 65; Vell. 2.8.3; Front. Strat. 2.4.3; Flor. 1.39.3-5; Amm. 27.4.10; Eutr. 4.27.5; Fest. Brev. 9.2; CIL I ${ }^{2}$, 2.692; Bull. Épigr. 1934, n. 230; Fasti Triumph. (106). See Th. Sarirakes, Romaioi Archontes Tai Eparkias Makedonias (Tessalonike 1971), pp. 55-63.

$5^{1}$ See n. 39. On the accusations: Vel. 2.81; Cic. 2.Verr. 4.24; Balb. 28. C. Cato was a moneyer in 123 BC according to M.H. Crawford, Roman Republican Coinage (Cambridge, 1974), n. 274.

$5^{2}$ For a discussion on literary and epigraphic sources for Minucius Rufus' campaigns, see: L. Amela, 'Sexto Pompeyo, pp. 31-32; M. Zahariade, The Thracians, p. 45; P. Delev, 'The burning of the temple, pp. 91-93.

53 See also: Flor. 1.39.5, Fest. 9; Iordan. 219. E. Drakopoulos, 'Titus Didius and his Macedonian Praetorship', Ancient World 21 (1990), pp. 123-126; M. Zahariade, The Thracians, p. 46. T. Didius, as a monneyer in 113, issued coins depicting gladiatorial combats between Galli who could easily be Scordisci prisoners: M.H. Crawford, Roman Republican Coinage, n. 294 (p. 308); J.-L. Desnier, 'Le gaulois dans l'imaginaire monétaire de la République. Images plurielles d'une réalité singulière', Mélanges de l'École Francaise de Rome 103.2 (1991), pp. 605-654 (pp. 625-626). 
at 100, just after his former operations in integrating the south-eastern part of Thrace ('Caenice' and 'Chersonese') into Macedonia the year before. ${ }^{54}$ For the next decade or so, the situation became equally unsettled. Roman policy regarding the Thracian tribes was based on bilateral surrendering treaties which were not always sufficient to maintain peace, especially with the new uprisings as mentioned in 97 (Obs. 48) and 92 (Liv. Per. 70; Obs. 53). ${ }^{55}$

Finally, a passage from Justin helps us to understand the complexity of the interstate politics and the military scenario existing on the verge of the First Mithridatic War. According to Justin, Mithridates sent legates to the Cimbrians, who had been recently defeated by Rome but whose experience in fighting the Romans would be quite useful, along with the Gallograeci, Sarmatae, Bastarnae and later, the Scythians, searching for military support in his foreseeable campaign against Rome (Just. $38.3 \cdot 6-7$ ) ${ }^{56}$ The Thracians are not mentioned in this passage, although in his book on the Mithridatic Wars, Appian refers several times to the fact that the Thracians fought in the Pontic armies simply as allies (summachoi)..$^{57}$ The most likely explanation for Justin's argumentum e silentio is that Mithridates already counted on Thracian mercenaries in his armies at that specific moment and there was no need to recruit more. ${ }^{58}$ Having said this, only the coin evidence has shed some light on Mostis, a Thracian king who most likely provided Mithridates with Thracian soldiers, although surprisingly, the classical literature remains silent on this remarkable figure. ${ }^{59}$ Unlike

54 Cnidos Copy, Column IV, ll. 5-30 and esp. 8-9: M.H. Crawford (ed.), Roman Statutes, vol. 1 (London, 1996), p. 241 and commentary p. 264; F.K. Drogula, 'The Lex Porcia and the Development of Legal Restraints on Roman Governors' Chiron 41 (2011), pp. 91-124 (pp. 115 ff.).

55 M. Zahariade, The Thracians, p. 47 wrongly places C. Sentius Saturninus' actions against Thracians in 97, when they occurred in 92.

$56 \quad$ Post haec Mithridates intellecto quantum bellum suscitaret, legatos ad Cimbros, alios ad Gallograecos et Sarmatas Bastarnasque auxilium petitum mittit. Nam omnes has gentes Romanum meditabundus bellum variis beneficiorum muneribus iam ante inlexerat. Ab Schythia quoque exercitum venire iubet omnemque Orientem adversus Romanos armat.

57 App. Mithr. 13; 15; 41; 57;69.

$5^{8}$ The 'barbarian' composition of Pontic armies is well known, as is the key role reserved to the Thracians in these armies. See recently J.-Ch. Couvenhes, 'Larmée de Mithridate VI Eupator d'après Plutarque, Vie de Lucullus, VI, 4-6', in H. Bru, F. Kirbihler, S. Lebreton (éds.), L'Asie Mineure dans l'Antiquité. Échanges, populations et territoires (Rennes, 2009), pp. 415-438 (p. 423).

59 Y. Youroukova, Coins of the Ancient Thracians, British Archaeological Reports, Suppl.Ser.4 (Oxford, 1976), pp. 38-39; a more sceptical view on such coins by F. de Callataÿ, L'histoire des guerres, pp. 256-258; D. Dana, 'Inscriptions', Companion to Ancient Thrace, pp. 243264 (p. 252); E.I. Paunov, 'Introduction to the Numismatics of Thrace, ca. 530 BCE-46 CE', Companion to Ancient Thrace, pp. 265-292 (pp. 275 ff.). 
Pontic armies, Roman legions first employed Thracian auxiliaries during the Mithridatic conflict, when the most powerful Thracian tribe, the Ordrysians, not only became a client kingdom of Rome's but also their most devoted military ally against Pontus. According to a well known inscription, the Thracian prince Sadalas sided with Sulla during the same military conflict, providing auxiliaries to support his legions. ${ }^{60}$ Regardless, the continuation of Thracian uprisings after the final outcome of the war against Mithridates for over a century clearly indicates that Rome never intended to replace the old Hellenistic kingdoms as a mercenary and auxiliary employer of the Thracian soldiers. After the Social War, the Italians who used to serve as auxiliaries in the Roman armies were finally accepted in the core of the legions as proper Roman citizens. Therefore, in order to achieve Rome's dominion over Thrace, a preliminary step became necessary, and that was the military disintegration of the Thracians who would eventually be integrated as auxiliaries into the Roman armies, but only upon their final conquest during the Roman Empire. ${ }^{61}$

\section{3}

\section{Conclusions}

The Roman dominions in Macedonia, Achaia and later, in Asia, were subject to continuous military pressure exercised by individuals belonging to peoples from beyond the Roman borders, since roughly the mid-second century. We have focused our analysis on two relevant case studies: Pontus and Thrace. Firstly, Mithridates' success in the Cimmerian Bosporus and Colchis as well as with his victories over the Scythians, Sarmatians and other populations from the Black Sea, never seemed to alter Rome's plans for the region. It is likely to believe that the extensive troubles in the West contributed to Rome's previous lax attitude towards the Pontic expansionism in the Black Sea, and perhaps even to its intervention in Anatolia, which was ultimately the main cause of the Mithridatic wars. After all, Pontus was never militarily integrated into the Imperium Romanum but was defeated in a long series of wars. Rome's definitive settlement of the lands from the Black Sea area was conducted from Macedonia and Asia much later, during the second half of the first century AD. Only then were the provinces of Thrace and Pontus created and Bosporus remained a

6o Caes. Civ. 3.4.3; Civ. 2Verr. 1.63, Luc. Civ. 5.54. M. Holleaux, 'Décret de Chéronée relatif à la première guerre de Mithridates', Revue des Études Grecques 32 (1919), pp. 320-337; M. Zahariade, The Thracians, p. 48; Delev, From Koroupedion, pp. 70, 72.

61 P. Delev, From Koroupedion, pp. 70-72; I. Lozanov, 'Roman Thrace', Companion to Ancient Thrace, pp. $75^{-90}$ (pp. $75^{-78}$ ). 
client kingdom of certain entity. Thus, the Pontic area constituted an extension of the Danubian limes which separated the Roman and Parthian Empires.

Secondly, the traditional role of the Thracians as mercenaries and auxiliaries enrolled in foreign armies faced a twofold problem during the last decades of the second century, having a major influence on their future integration in the Roman world. In the first place, the Thracian tribes experienced a progressive lack of employers when some of the Hellenistic powers and their armies began to lose their primary role in interstate politics and finally ceased to exist. Then, the general unrest in the Balkans provoked by the Cimbrian invasions also triggered new raids by Scordisci Gauls and other nomadic peoples towards the Roman province of Macedonia. Rome was therefore forced to intervene with obscure campaigns that have never been well explained because the historical evidence is quite limited. The Thracian realpolitik may be also observed just before and during the Mithridatic conflict, when both parties received their military support. Of course, it was too late for the Roman Republic to militarily integrate such people, as if Rome were another Hellenistic power. When the Thracians realized this, endless uprisings continued to occur for over almost two centuries until a province was eventually created in Thrace. 